\title{
The Effects of Listening Conditions on Sentence Judgement and Listening Effort in School-Aged Children with Bilateral Cochlear Implants in a Dual-Task Paradigm
}

\author{
Youngmee Lee ${ }^{a}$, Hyun Sub Sim ${ }^{b}$ \\ a Department of Communication Disorders, Tongmyong University, Busan, Korea \\ ${ }^{b}$ Department of Communication Disorders, Ewha Womans University, Seoul, Korea
}

Correspondence: Hyun Sub Sim, PhD Department of Communication Disorders, Ewha Womans University, 52 Ewhayeodae-gil, Seodamun-gu, Seoul 03760, Korea

Tel: $+82-2-3277-3538$

Fax: +82-2-3277-2122

E-mail: simhs@ewha.ac.kr

Received: May 1, 2018

Revised: August 13, 2018

Accepted: August 13, 2018

This article is based on a part of the first author's doctoral dissertation from Ewha Womans University.

\begin{abstract}
Objectives: This study investigated the impact of bilateral cochlear implantation on auditory-language processing abilities and listening effort for deaf children in quiet and noise conditions using a dual-task paradigm. Methods: Seventeen children with bilateral cochlear implants (BiCl group), 17 children with unilateral cochlear implants (UniCl group), and 17 children with normal hearing ( $\mathrm{NH}$ group) participated in this study, and they ranged from 7 to 14 years at the testing. Dual tasks involved judging the semantic plausibility of auditorily presented sentences under quiet and noise conditions (primary task) and responding in a digit judgment task in which two digits were visually presented on the screen (secondary task). Results: On the dual task, all children performed better when tested in quiet rather than in noise. On the sentence judgement task, BiCl group performed with higher accuracy and faster processing speed than UniCl group with and without noise. On the digit task, $\mathrm{NH}$ group showed significantly quicker response times than $\mathrm{BiCl}$ and UniCl groups. Conclusion: $\mathrm{BiCl}$ group processed sentence semantically more accurately and faster than UniCl group with the same listening effort. These findings suggest that bilateral cochlear implantation is more beneficial than unilateral cochlear implantation in deaf children in improving auditory-language processing abilities.
\end{abstract}

Keywords: Dual-task paradigm, Bilateral cochlear implants, Children, Sentence judgement, Listening effort
학령기 아동이 학교생활에 원활하게 참여하기 위해서는 교사와 또래의 말소리를 정확하게 듣고 이해해야 한다. 하지만, 일반적인 교실 상황에서는 아동이 움직이면서 내는 소리와 기계음 등의 다 양한 소음이 발생되어, 아동은 차단되거나 왜곡된 청각정보를 지각 하게 된다(Flexer \& Rollow, 2009; Howard, Munro, \& Plack, 2010). 호주 라트로브대학교(La Trobe University) 심리학과와 인공와우 연구소(The Bionic Ear Institute)가 말지각(speech perception)과 소음의 관련성에 관한 공동연구를 진행한 결과에서 아동이 소음 조건에서 말소리를 듣고 이해하는 능력이 성인보다 취약한 것으로 나타났으며, 울산대학교 작업환경의학과 연구에서는 교실 소음이
$65 \mathrm{~dB}$ 인 상태에서 아동의 과제에 대한 반응속도, 주의력, 기억력 등 이 조용한 조건에 비해 5\%-15\%까지 감퇴하는 것으로 나타났다(SisaTimes, 2018). 학교 상황에서 아동은 교실 내에서 교사의 말을 들 으면서 여러 가지 과제(예: 필기하기, 본인 지식과 통합하기, 그림 그 리기)를 해야 하는 다중작업(multi-tasking) 상황에 놓이게 되는 경우가 많다. 이때, 교실 내 소음이 심각한 수준이라면, 교사의 말 을 이해하는 데 필요한 인지 노력(cognitive effort)이 증가되어, 다 른 과제를 동시에 정확하고 빠르게 수행하는 데 어려움을 겪게 된 다(Howard et al., 2010).

청각장애 아동의 말지각이 조용한 조건에서 정상청력 아동과 비 
슷하더라도, 소음 조건에서는 화자의 말을 이해하는 능력은 현저하 게 낮아진다(Plomp, 1994). 그리고 청각 손실 정도가 심각할수록 소음 조건에서 말을 이해하는 능력은 더욱 떨어진다(Killion, 1997). 이는 청각장애 아동이 음향-음소 정보가 저하된 청각정보를 이해 하기 위해서 정상청력 아동에 비해 더 많은 선택적 집중과 인지 노 력이 필요하다는 것을 시사한다(Hicks \& Tharpe, 2002). 특히, 소 음이 심각한 교실에서 청각장애 아동이 다중작업을 해야 하는 상 황이라면, 교사나 또래 말을 이해하는 것과 함께 다른 과제의 수행 도 함께 저하될 수 있을 것이다. 소음은 말초청각수준(peripheral auditory level)에서 말소리 변별에 필요한 음향-음소 정보의 양을 감소시키며, 중추청각수준(central auditory level)에서 말소리를 언 어적으로 처리하는 데 인지적 부담을 가중시켜서 청각장애 아동이 상대방의 메시지 이해를 방해한다(Howard et al., 2010; Papso \& Blood, 1989; Pichora-Fuller, \& Singh, 2006; Sarampalis, Kalluri, Edwards, \& Hafter, 2009).

세계보건기구(World Health Organization, WHO)의 국제기능 장애건강분류(International Classification of Functioning, Disability, and Health)에서는 듣기(listening)를 정신적 노력과 집중이 요구되는 청각정보처리 과정이라고 언급하였다(WHO, 2001). 이러 한 $\mathrm{WHO}$ 의 제안에 따라, 청각재활전문가는 청각장애인의 청각 기 능(auditory functioning)을 단순히 청력검사 결과 이외에 상대방 의 의도, 정보처리, 인지 노력이 요구되는 능동적인 과정으로 이해 하는 인식을 가지게 되었다. 이로 인해, 청각장애인의 말지각과 인 지와의 상호작용에 초점을 맞추어 평가, 검사 및 연구를 진행하는 능동적인 관점이 생겨나게 되었다(Kiessling et al., 2003). 그리고 청 각장애인의 의사소통 및 학습의 어려움을 나타내는 척도 중의 하 나로 듣기 노력(listening effort)에 대한 관심이 높아지게 되었다.

듣기 노력은 청자가 화자의 말을 이해하는 데 필요한 노력으로, 여기에 사용된 집중과 인지 자원(cognitive resources)을 말한다 (Downs \& Crum, 1978; Fraser, Gagné, Alepins, \& Dubois, 2010; Hicks \& Tharpe, 2002). 선행연구에서는 Kahneman (1973)이 제안 한 제한인지용량(limited cognitive capacity) 모델을 근거로 한 이 중과제 패러다임(dual-task paradigm)을 이용하여 듣기 노력의 정 도를 측정하고 있다. 다양한 대상자의 듣기 노력의 정도를 측정하 기 위해서 이중과제를 개발할 때는 일차과제(primary task)는 단어 나 문장인지과제로, 이차과제(secondary task)는 기억과제(memory task), 탐사시간 반응과제(probe response time task), 촉각패턴과 제(tactile pattern recognition task) 등으로 구성한다(Downs \& Crum, 1978; Fraser et al., 2010; Gosselin \& Gagné, 2011; Hicks \& Tharpe, 2002). 대상자가 일차과제를 수행하는 데 많은 집중과 인
지 자원을 사용하게 되면, 남은 인지용량(spare cognitive capacity) 으로 수행하게 되는 이차과제의 정확도(accuracy)와처리속도(speed of processing)는 저하된다. 즉, 청자의 인지용량이 제한된 상태에 서 일차과제에 많은 인지 자원을 사용하게 되면 이차과제의 정확 도가 낮아지고 반응시간이 느려지는 등으로 수행력이 감소되게 되 는 것이다. 이때의 이차과제 수행력을 일차과제에서의 듣기 노력의 정도가 반영된 결과로 해석한다(Choi, Lotto, Lewis, Hoover, \& Stelmachowicz, 2008; Fraser et al., 2010; Gosselin \& Gagné, 2011; Hicks \& Tharpe, 2002; Larsby, Hällgren, Lyxell, \& Arlinger, 2005; Sarampalis et al., 2009). 이처럼, 듣기 노력의 측정은 청자가 학습과 의사소통 과정에서 겪을 수 있는 집중과 인지 노력에 대한 정보를 제공해줄 수 있으며, 청각장애 아동의 듣기 노력은 청각언어정보처 리능력과 일상생활에서의 듣기 어려움을 파악하는 데 도움을 줄 수있다.

듣기 노력에 관한 연구는 주로 성인을 대상으로 진행되었으며, 청 각장애 분야에서는 양이청(binaural hearing)의 효과를 확인하기 위하여 언어 습득 후 농이 된 성인을 대상으로 일측과 양측 인공와 우이식(cochlear implantation) 상태에서의 듣기 노력에 관한 연구 가 보고된 바 있다(Dunn et al., 2010; Noble, Tyler, Dunn, \& Bhullar, 2008). Dunn 등(2010)은 양측 인공와우이식 성인과 일측 인공 와우이식 성인을 대상으로 소음 조건에서 문장을 듣고 따라 말하 면서 화면에 제시된 그림 중에서 가장 많은 색깔을 포함하고 있는 그림을 지적하는 과제를 실시하였다. 그 결과, 양측 인공와우이식 성인이 문장 따라말하기와 그림 지적하기 과제 모두에서 일측 인공 와우이식 성인에 비해 더 높은 정확도를 보였다. Noble 등(2008)이 양측 인공와우이식 성인, 일측 인공와우이식 성인, 인공와우와 보 청기를 착용한 성인에게 본인이 지각하는 듣기 노력 정도에 대한 자 기 평정을 실시한 결과에서도 양측 인공와우이식 성인이 의사소통 상황에서 다른 대상자에 비해서 듣기 노력을 적게 사용하는 것으 로 나타났다. 이러한 결과들은 양측 인공와우이식이 소음 조건에 서 청각장애인이 말소리를 이해하는 데 필요한 인지부하를 감소시 켜, 듣기 노력 감소에도 도움에 된다는 것을 시사한다.

선행연구를 살펴보면, 학령기 아동을 대상으로 듣기 노력을 측 정한 연구는 미비하며, 대상군도 정상청력 아동에 초점을 맞추어 진행된 경향이 있다. Choi 등(2008)은 소음 조건에서 단음절단어검 사와 숫자 회상하기로 구성된 이중과제를 정상청력 아동에게 실시 한 결과, 단일과제일 때보다 이중과제일 때의 정확도가 낮아지고 반응시간이 늦어졌다. Howard 등(2010)의 연구에서는 여러 듣기 조건(조용한 조건, $-4,0,+4 \mathrm{~dB} \mathrm{SNR}$ )에서의 단음절단어검사와 숫 자 회상하기로 구성된 이중과제를 정상청력 아동에게 실시한 결과, 
신호대잡음비(signal-to-noise ratio, SNR)가 낮아져도 일차과제인 단음절단어검사의 점수는 유지되는 반면에, 이차과제인 숫자 회상 하기의 점수는 유의하게 낮아졌다. 이는 소음으로 인해 청각언어정 보처리에 사용되는 집중과 인지 자원이 증가되어, 숫자 회상하기와 같은 이차과제에서의 정확도가 저하된 것으로 해석할 수 있다. 즉, 학령기 아동의 인지 용량이 제한된 상황에서 말을 이해하는 데 필 요한 인지 요구가 증가되면, 효율적인 의사소통과 학습을 위한 정 보 회상 및 환경 탐색에 사용할 인지 자원이 부족하게 되는 것이다 (Picou, Ricketts, \& Hornsby, 2011).

인공와우이식 아동의 말지각, 언어 발달에 관한 연구는 국내외 에서 활발히 진행되어 왔지만, 인공와우이식 아동의 듣기 노력에 관한 연구결과는 살펴보기 힘들다. 양측 인공와우이식의 효능성에 관한 연구에서는 양측 인공와우이식 아동의 소리 방향성(sound localization)과 소음 조건에서의 말지각이 일측 인공와우이식 아동 보다 우수하며(Eapen, Buss, Adunka, Pillsbury, \& Buchman, 2009; Galvin, Mok, Dowell, \& Briggs, 2008; Lee \& Sim, 2015), 최근에는 조기에 양측 인공와우이식을 시행할 경우, 말지각 발달뿐만 아니 라 빠른 말, 언어 발달도 가능하다고 보고되고 있다(Baudonck, Lierde, D'haeseleer, \& Dhooge, 2011; Boons et al., 2012). 하지만, 이러 한 기존 연구에서는 임상적 검사도구를 이용하여 결과를 해석하였 기 때문에, 양측 인공와우이식으로 얻게 된 양이청이 말, 언어 학습 에 어떻게 긍정적인 작용을 하였는지 증명하기는 어렵다. 본 연구 에서는 이중과제 패러다임에 근거하여 개발한 과제를 이용하여 양 측 인공와우이식의 효능성을 청각언어정보처리능력과 듣기 노력 의 정도로 확인함으로써, 양측 인공와우이식이 청각장애 아동의 의사소통과 학습에 미치는 긍정적인 효과에 대해서 탐색해보고자 하였다. 이에 따라, 본 연구에서는 듣기 조건(조용한 조건, 소음 조
건)과 집단(일측 인공와우이식 아동, 양측 인공와우이식 아동, 정 상청력 아동)에 따른 문장 판단하기와 숫자 판단하기의 이중과제 수행력에 유의한 차이가 있는지 살펴보았다. 구체적인 연구질문은 다음과같다.

1) 듣기 조건과 집단에 따른 문장 판단하기(일차과제)의 정확도 와 반응시간에 유의한 차이가 있는가?

2) 듣기 조건과 집단에 따른 숫자 회상하기(이차과제)의 반응시 간에 유의한차이가 있는가?

\section{연구방법}

\section{연구대상}

본 연구에서는 정상청력 아동(17명), 일측 인공와우이식 아동(17 명), 양측 인공와우이식 아동(17명)이 참여하였다. 정상청력 아동 은 (1) 생활연령이 7세에서 14세에 해당하며, (2) 청력검사기기(WRC Audiometry; Qualitone industrial Inc., New York, NY, USA)로 실시한 청력검사에서 $0.5,1,2,4 \mathrm{kHz}$ 주파수에서 $20 \mathrm{~dB}$ 이내이며, (3) 수용-표현어휘력검사(Receptive \& Expressive Vocabulary Test; Kim, Hong, Kim, Jang, \& Lee, 2009)에서 수용어휘 점수가 -1 표준 편차 이내에 속하고, (4) 부모 보고에 의해 말, 언어 발달에 문제가 없는 대상자만이 실험에 참여하였다. 일측 인공와우이식 아동은 (1) 생활연령이 7세에서 14세에 해당되며, (2) 선천성 농(congenital deaf)이며, (3) 3.5세 이전에 인공와우이식을 시행받고, (4) 중복장 애나 심한 내이기형이 없으며, (5) 통합교육 상황에서 구어 의사소 통을 하는 경우만을 대상으로 선정하였다. 양측 인공와우이식 아 동은 일측 인공와우이식 아동의 선정기준과 동일하되, 두 번째 인 공와우 사용기간이 1년 이상인 아동만이 실험에 참여하였다 $(\mathrm{Gal}-$

Table 1. Participants' characteristics

\begin{tabular}{|c|c|c|c|}
\hline & $\mathrm{NH}$ group $(\mathrm{N}=17$ ) & $\mathrm{BiCl}$ group ( $\mathrm{N}=17$ ) & UniCl group ( $\mathrm{N}=17)$ \\
\hline Age (mo) & $116.8 \pm 23.1(78-150)$ & $128.9 \pm 36.2(83-174)$ & $131.1 \pm 26.2(82-167)$ \\
\hline \multicolumn{4}{|l|}{ Sex } \\
\hline Male & 6 & 9 & 9 \\
\hline Female & 12 & 9 & 9 \\
\hline Age of the first $\mathrm{Cl}$ (mo) & - & $30.4 \pm 7.7(19-42)$ & $32.7 \pm 8.5(21-42)$ \\
\hline Age of the second $\mathrm{Cl}(\mathrm{mo})$ & - & $91.4 \pm 27.4(53-136)$ & - \\
\hline Duration of the first $\mathrm{Cl}(\mathrm{mo})$ & - & $98.5 \pm 31.4(55-149)$ & $98.4 \pm 28.1(40-145)$ \\
\hline Duration of the second $\mathrm{Cl}(\mathrm{mo})$ & - & $37.5 \pm 14.8(16-57)$ & - \\
\hline REVT-R & $107.5 \pm 25.3(68-147)$ & $103.7 \pm 38.2(61-167)$ & $110.7 \pm 33.1$ (52-158) \\
\hline Monosyllabic word test (\%) & $96.6 \pm 2.2(91.5-100.0)$ & $87.6 \pm 6.4(71.5-96.2)$ & $81.4 \pm 9.4(67.7-91.5)$ \\
\hline
\end{tabular}

Values are presented as mean $\pm \mathrm{SD}$ (range).

$\mathrm{NH}=$ children with normal hearing; $\mathrm{BiCl}=$ children with bilateral cochlear implants; UniCl=children with unilateral cochlear implants; REVT-R=Receptive and Expressive Vocabulary Test-Receptive (Kim, Hong, Kim, Jang, \& Lee, 2009); Monosyllabic word test (Lee, Shin, Kim, \& Kim, 2009). 
vin et al., 2008).

본 연구에 참여한 아동의 생활연령, 성별, 첫 번째 인공와우이식 연령, 두 번째 인공와우이식 연령, 첫 번째 인공와우 사용기간, 두 번째 인공와우 사용기간, 수용어휘 점수(Kim et al., 2009), 단음절 단어검사(Lee, Shin, Kim, \& Kim, 2009)에 대한 기술통계 결과는 Table 1에 제시하였다. 집단 간 대상아동의 생활연령, 첫 번째 인공 와우이식 연령, 첫 번째 인공와우 사용기간, 수용어휘 점수에 대한 동질성 검정을 위해 일원배치분산분석(one-way ANOVA)을 실시 하였다. 그 결과, 세 집단 간에 생활연령 $\left(F_{(2,50)}=.730, p>.05\right)$, 수용 어휘 점수 $\left(F_{(2,50)}=0.538, p>.05\right)$ 에 유의한 차이가 없었으며, 일측과 양측 인공와우이식 아동 집단간에 첫 번째 인공와우이식 연령 $\left(F_{(1,33)}\right.$ $=2.374, p>.05)$ 과 첫 번째 인공와우 사용기간 $\left(F_{(1,33)}=0.003, p>.05\right)$ 에도 유의한 차이가 없었다. 조용한 조건에서 실시한 단음절단어검 사의 음소점수에서는 집단간에 유의한 차이가 있었다 $\left(F_{(2,50)}=22.815\right.$, $p<.001)$. 사후검정을 실시한 결과, 정상청력 아동과 양측 인공와우 이식 아동 $(p<.01)$, 정상청력 아동과 일측 인공와우이식 아동 $(p<$ $.001)$, 양측 인공와우이식 아동과 일측 인공와우이식 아동 $(p<.05)$ 간에 모두 유의한차이를 보였다.

\section{연구도구}

본 연구에서는 듣기 조건에 따라 아동이 청각언어정보를 처리하 는 정확도 및 속도, 듣기 노력을 평가하기 위해서, Fraser 등(2010)의 이중과제 패러다임 연구를 근거로 문장 판단하기(일차과제)와 숫 자 판단하기(이차과제)로 구성된 이중과제를 제작하였다. 대상아 동은 조용한 조건과 소음 조건에서 문장을 듣고 빠르고 정확하게 의미를 판단하며, 정해진 자극시차(stimulus onset asynchrony)로 화면에 제시되는 2 개의 숫자를 보고 더 큰 숫자를 빠르고 정확하게 지적하도록 하였다.

\section{문장 판단하기 과제}

문장 판단하기 과제는 한국어 문법과 어휘의 영향을 최소화하 기 위해서 다음과 같은 기준에 따라 문장을 제작하였다. 한국어 문 법 통제를 위해서, 문장은 (1) 2어절의 단문으로, (2) 어절당 음절수 는 2-4음절로 제한하고, (3) 문장 형식은 '주어+서술어(형용사)'로 제한하였다. 문장에 사용된 어휘는 (1) Kim (2003)의 '등급별 국어 교육용 어휘'와 Cho (2000)의 '한국어 어휘교육 연구'에 수록된 고 빈도 어휘만으로 선정하되, (2) 은유적, 비유적, 의인화 표현이 가능 한 어휘는 제외하고, (3) 아동에게 의미적으로 모호함을 줄 수 있는 어휘는 제외하였다. 이러한 기준에 따라서 총 문장 70 개를 제작하 였으며, 문장이 의미적으로 정오를 판단하는 데 적합한지 알아보
기 위해서 초등학교 2 학년 아동 10 명을 대상으로 타당도 점검을 하 였다. 이때, 아동 10 명이 모두 정반응한 문장 58 개 중에서 어휘가 중복되지 않는 문장만을 선정하여, 연습문항 5 개, 본 문항 32 개를 최종적으로 선정하였다(Appendix 1). 최종문항 32 개는 듣기 조건 (조용한 조건, 소음 조건)에 따라 16 개씩 배치하였으며, 순서효과와 학습효과를 배제하기 위해서 듣기 조건에 따른 제시 순서는 교차 균형화(counter-balancing)하였다.

본 과제는 아동에게 청각적으로 문장을 들려주고 아이패드(iPad; Apple Inc., Cupertino, CA, USA) 화면에 제시되는 정오 반응판에 서 정답을 선택하도록 하였다. 정오 반응판은 아이패드 화면의 상 단에 각각 $550 \mathrm{~mm} \times 550 \mathrm{~mm}$ 크기로 좌우에 배치하였다(Figure 1). 이러한 내용을 토대로 문장 판단하기 과제를 아이패드 환경에 서 구현될 수 있도록 프로그래밍하여, 아동이 아이패드 화면에서 정오 반응판을 터치할 때 입력되는 수치를 이용하여 반응과 반응 시간(reaction time)이 자동적으로 측정될 수 있도록 하였다.

\section{숫자 판단하기 과제}

숫자 판단하기 과제는 문장 판단하기 과제와 동시적으로 진행되 도록 하였다. 본 과제에서는 아동이 아이패드 화면 하단에 제시되 는 2 개의 숫자판 $(550 \mathrm{~mm} \times 550 \mathrm{~mm})$ 중에서 더 큰 숫자를 선택하 도록 하였다. 이때, 숫자판에는 1-9 사이의 한 자리 숫자를 좌우에 배치하며, 숫자 조합은 엑셀의 난수 발생을 이용하여 구성하였다. 숫자 판단하기 과제는 문장 판단하기 과제가 제시된 후 $400 \mathrm{ms,}$ $800 \mathrm{~ms}$ 의 자극시차로 아이패드 화면에 나타나며(Goldberg, Maurer, Lewis, \& Brent, 2001), 각 자극시차는 듣기 조건에 따라 8개씩 제시되도록 하였다(Figure 1). 이 내용을 토대로 숫자 판단하기 과

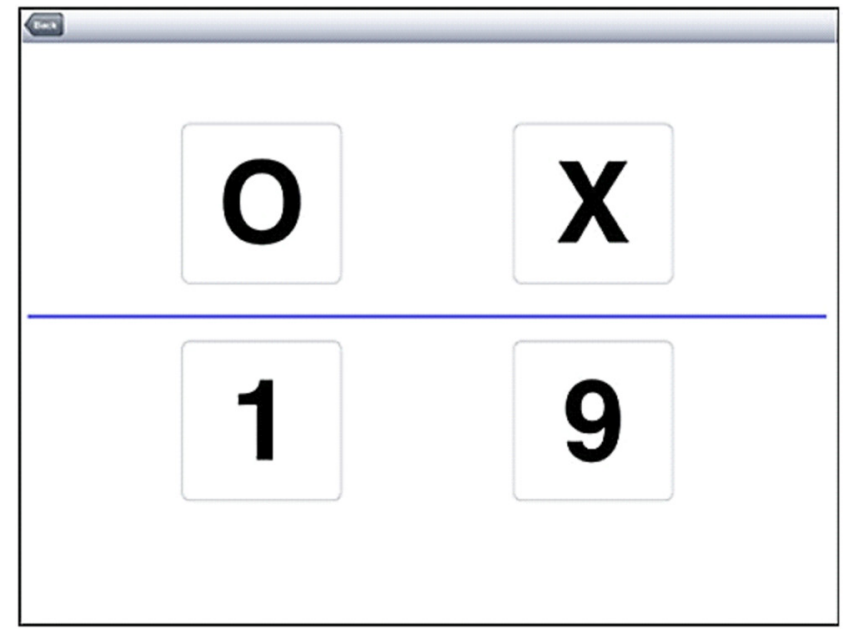

Figure 1. Screen for the dual-task. 
제를 아이패드 화면에 구현될 수 있도록 프로그래밍하여 자동적으 로 문항별 반응시간이 측정될 수 있도록 하였다.

\section{음성 녹음 작업}

제1연구자가 방음부스(SA-1200 single wall; SonTek, Paju, Ko$\mathrm{rea})$ 에서 문장 판단하기 과제의 문장을 디지털 녹음기(EDIROL R09HR; Roland Corp., Los Angeles, CA, USA)를 이용하여 녹음하 였다. 실험에 사용된 문장은 평균 2.29 초 $(\mathrm{SD}=.265)$ 로 녹음되었으 며, 평균 말속도는 1 초당 3.4 음절 $(\mathrm{SD}=.38)$ 이었다. 녹음된 음성파일 은 GoldWave 5.58 프로그램(GoldWave Inc., St. John's, NL, Cana$\mathrm{da}$ )을 이용하여 편집하였으며, 이때, 각 문장의 시작과 끝에 $200 \mathrm{~ms}$ 의 묵음 구간을 삽입하였다.

소음 조건에서 사용될 음성파일을 제작하기 위하여 ITU-T 프로 그램(International Telecommunication Union, Geneva, Switzerland)을 이용하여 편집한 문장의 음성파일에 다화자 잡음(NOISEX 92 Database)을 추가하였다. 먼저, 편집한 음성파일과 소음의 음 성파일의 길이를 동일하게 조정하고, 녹음된 음성 강도를 기준으 로 소음의 신호를 $+8 \mathrm{~dB}$ 의 신호대잡음비로 조정하였다(Choi et al., 2008; Wackym, Runge-Samuelson, Firszt, Alkaf, \& Burg, 2007). 마 지막으로 동일한 시간 영역에서 편집한음성에 조정된 소음을 추가 하여, 아동에게 들려줄 최종적인 문장의 음성파일을 제작하였다.

\section{연구절차}

실험은 대학병원 내 청력검사실 방음부스(SA-1200 single wall) 에서 대상아동에게 개별적으로 실시하였다. 문장 판단하기 과제의 음성 자극은 아동의 정면에 배치된 스피커에서 $70 \mathrm{~dB} \mathrm{SPL}$ 의 강도 로 제시하였으며, 아동은 편안하게 앉아서 스피커에 들리는 음성 을 듣고 지시사항에 따라 반응하도록 하였다. 이때, 문장 판단하기 와 숫자 판단하기 과제의 지시사항은 아이패드 화면에 시각적으로 도 제시하였으며, 연습문항을 통해서 아동이 검사절차를 충분히 숙지하도록 하였다. 연습문항을 실시하는 동안, 아동과 스피커와 의 거리, 아이패드 위치, 아동과 아이패드 화면과의 거리를 조정하 여, 아동이 실험에 편안하게 참여할 수 있도록 환경을 조성하였다. 그리고 모든 아동에게 같은 강도의 음성 자극을 제시하기 위하여, 실험 시작 전에 매번 청력검사기기의 교정(calibration) 작업을 실시 하였다.

\section{자료분석}

문장 판단하기 과제의 정확도는 듣기 조건에 따른 문항수에서 아동이 정확하게 반응한 문항의 수를 백분율(\%)로 산출하였다. 아
동이 문장의 의미를 적절하게 판단한 경우를 정답(1점), 그렇지 않 은 경우를 오답(0점)으로 채점하였으며, 각 듣기 조건에서 문장 판 단하기 정확도는 $0 \%-100 \%$ 로 산출되도록 하였다.

선행연구(Fraser et al., 2010; Gosselin \& Gagné, 2011)에서 제시 한 이중과제의 분석절차를 근거로 하여, 문장 판단하기 과제의 반 응시간은 정반응한 경우만을 분석하며, 숫자 판단하기 과제의 반 응시간은 문장 판단하기와 숫자 판단하기 과제 모두에서 정반응한 경우에 한해서 분석하였다. 이때, 아동의 주의집중 부족으로 반응 시간이 지연되는 경우를 배제하기 위해서, 각 듣기 조건에서 개인 내 반응시간의 평균에서 +3 표준편차 이상의 결과는 분석에서 제 외하였다(Miller, 1991).

\section{자료의 통계적 처리}

본 연구의 자료분석은 IBM SPSS Statistics version 24 (IBM Co., Armonk, NY, USA)를 사용하였다. 듣기 조건과 집단에 따른 문장 판단하기의 정확도 및 반응시간, 숫자 판단하기의 반응시간에서의 차이를 살펴보기 위해서, 이원 혼합분산분석(two-way mixed ANOVA)를 실시하였다.

\section{연구결과}

\section{일차과제 수행력: 문장 판단하기의 정확도 및 반응시간}

듣기 조건(조용한 조건, 소음 조건)에 따른 정상청력 아동, 양측 인공와우이식 아동, 일측 인공와우이식 아동의 문장 판단하기의 정확도에 대한 기술통계는 Table 2에 제시하였다.

구형성 가정을 검정한 결과, 듣기 조건(Mauchly's $\mathrm{W}=1.00, \chi^{2}=$ $.00, p<.05)$ 이 공분산의 동질성 가정에 위배는 것으로 나타나서 Greenhouse-Geisser의 $F$ 값으로 통계 결과를 해석하였다. 이원혼 합분산분석을 실시한 결과, 집단에 따른 문장 판단하기의 정확도 에 대한 주효과가 유의하였다 $\left(F_{(2,48)}=40.506, p<.001, \operatorname{partial} \eta^{2}=\right.$ .628). 어느 집단에서 유의한 차이가 있는지 살펴보기 위해서 Bonferroni 사후검정을 실시한 결과, 모든 집단 간에 문장 판단하기의

Table 2. Accuracy of sentence judgment for three groups according to the quiet and noise conditions

\begin{tabular}{lccc}
\hline \multirow{2}{*}{ Listening condition } & \multicolumn{3}{c}{ Accuracy $(\%)$} \\
\cline { 2 - 4 } & NH group & BiCl group & UniCl group \\
\hline Quiet & $97.65 \pm 3.03$ & $81.39 \pm 13.17$ & $70.57 \pm 18.52$ \\
Noise & $95.00 \pm 5.79$ & $66.91 \pm 15.59$ & $58.46 \pm 11.04$ \\
\hline
\end{tabular}

Values are presented as mean \pm SD.

$\mathrm{NH}=$ children with normal hearing; $\mathrm{BiCl}=$ children with bilateral cochlear implants; UniCl= children with unilateral cochlear implants. 
정확도에서 유의한 차이가 있었다(all $p$-values <.01). 듣기 조건에 대한 주효과도 유의하게 나타나서, 소음 조건에 비해 조용한 조건 에서 문장 판단하기의 정확도가 유의하게 높았다 $\left(F_{(1,48)}=28.647\right.$, $p<.001$, partial $\left.\eta^{2}=.374\right)$. 집단과 듣기 조건이 문장 판단하기의 정 확도에 미치는 이차 상호작용효과가 유의하였다 $\left(F_{(2,48)}=3.942\right.$, $p<.05$, partial $\eta^{2}=.141$ ). 사후검정으로 LMATRIX 및 MMATRIX 명령어를 사용한 대비검정을 실시한 결과, 이차상호작용효과는 정 상청력 아동과 양측 인공와우이식 아동 $(p<.01)$, 정상청력 아동과 일측 인공와우이식 아동 $(p<.01)$ 간 문장 판단하기의 정확도 차이 가 조용한 조건에 비해서 소음 조건에서 유의하게 커져서 나타난 결과이다(Figure 2).

듣기 조건에 따른 정상청력 아동, 양측 인공와우이식 아동, 일측 인공와우이식 아동의 문장 판단하기의 반응시간에 대한 기술통계 는 Table 3에 제시하였다.

이원혼합분산분석의 결과는 듣기 조건(Mauchly's W=1.00, $\chi^{2}=$ $.00, p<.05)$ 에 대한 구형성 가정이 충족되지 않아서 Greenhouse-

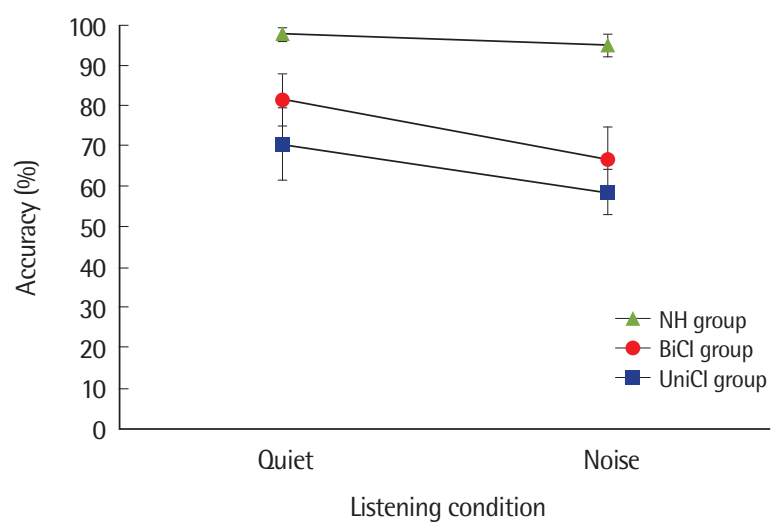

Figure 2. Accuracy of sentence judgment for children with normal hearing, children with bilateral cochlear implants, and children with unilateral cochlear implants according to the listening condition.

$\mathrm{NH}=$ children with normal hearing; $\mathrm{BiCl}=$ children with bilateral cochlear implants; UniCl = children with unilateral cochlear implants.

Table 3. Reaction time of sentence judgment for three groups according to the quiet and noise conditions

\begin{tabular}{lccc}
\hline \multirow{2}{*}{ Listening condition } & \multicolumn{3}{c}{ Reaction time (s) } \\
\cline { 2 - 4 } & NH group & BiCl group & UniCl group \\
\hline Quiet & $2.91 \pm 0.62$ & $3.79 \pm 0.76$ & $4.14 \pm 0.78$ \\
Noise & $3.15 \pm 0.64$ & $4.49 \pm 0.79$ & $4.95 \pm 0.88$ \\
\hline
\end{tabular}

Values are presented as mean \pm SD.

$\mathrm{NH}=$ children with normal hearing; $\mathrm{BiCl}=$ children with bilateral cochlear implants; $\mathrm{UniCl}=$ children with unilateral cochlear implants.
Geisser의 $F$ 값을 기초로 해석하였다. 문장 판단하기의 반응시간에 대한 집단의 주효과가 유의하였다 $\left(F_{(2,48)}=24.877, p<.001\right.$, partial $\left.\eta^{2}=.509\right)$. Bonferroni 사후검정을 실시한 결과, 반응시간은 정상청 력 아동, 양측 인공와우이식 아동, 일측 인공와우이식 아동 순으로 유의하게 길었다(all $p<.05)$. 듣기 조건에 대한 주효과도 유의하여 소음 조건에서 문장 판단하기의 반응시간이 조용한 조건에 비해서 유의하게 길었다 $\left(F_{(1,48)}=30.422, p<.001\right.$, partial $\eta^{2}=.388$ ) (Figure 3).

\section{이차과제 수행력: 숫자 판단하기의 반응시간}

듣기 조건에 따른 정상청력 아동, 양측 인공와우이식 아동, 일측 인공와우이식 아동의 숫자 판단하기의 반응시간에 대한 기술통계 결과는 Table 4에 제시하였다.

이원혼합분산분석 결과, 집단에 따른 숫자 판단하기의 반응시간 에 대한 주효과가 유의하였다 $\left(F_{(2,48)}=12.697, p<.001\right.$, partial $\eta^{2}=$ .346). Bonferroni 사후검정을 실시한 결과, 정상청력 아동과 일측 인공와우이식 아동 $(p<.001)$, 정상청력 아동과 양측 인공와우이식

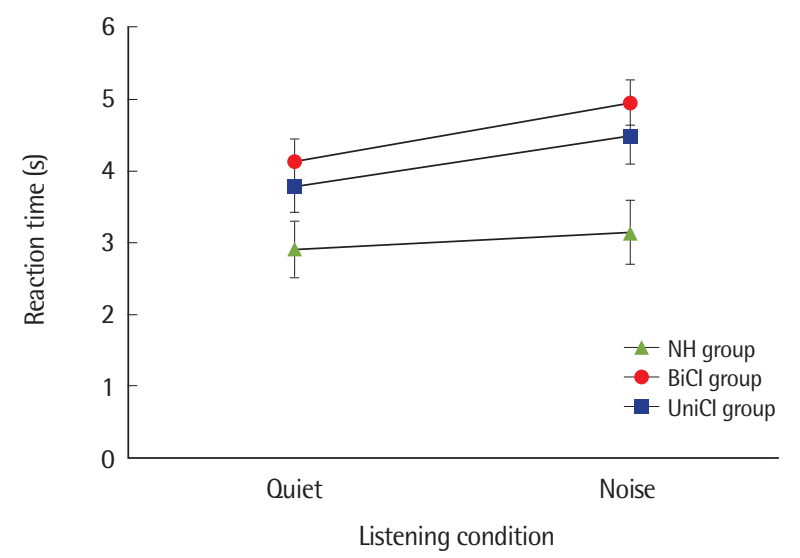

Figure 3. Response time of sentence judgment for children with normal hearing, children with bilateral cochlear implants, and children with unilateral cochlear implants according to the listening condition.

$\mathrm{NH}=$ children with normal hearing; $\mathrm{BiCl}=$ children with bilateral cochlear implants; UniCl= children with unilateral cochlear implants.

Table 4. Reaction time of digit judgment for three groups according to the quiet and noise conditions

\begin{tabular}{lccc}
\hline \multirow{2}{*}{ Listening condition } & \multicolumn{3}{c}{ Reaction time $(\mathrm{s})$} \\
\cline { 2 - 4 } & NH group & BiCl group & UniCl group \\
\hline Quiet & $3.46 \pm 0.84$ & $4.50 \pm 1.02$ & $4.55 \pm 0.87$ \\
Noise & $3.72 \pm 0.77$ & $5.09 \pm 0.81$ & $5.08 \pm 0.99$ \\
\hline
\end{tabular}

Values are presented as mean $\pm S D$.

$\mathrm{NH}=$ children with normal hearing; $\mathrm{BiCl}=$ children with bilateral cochlear implants; UniCl= children with unilateral cochlear implants. 


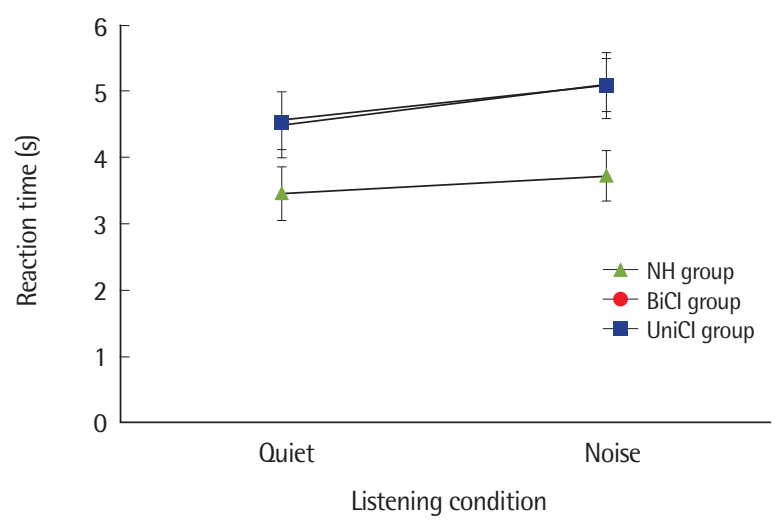

Figure 4. Response time of digit judgment for children with normal hearing, children with normal hearing, children with bilateral cochlear implants, and children with unilateral cochlear implants according to the listening condition. $\mathrm{NH}=$ children with normal hearing; $\mathrm{BiCl}=$ children with bilateral cochlear implants; UniCl= children with unilateral cochlear implants.

아동 $(p<.001)$ 간의 숫자 판단하기의 반응시간에서 유의한 차이가 나타났다. 즉, 일측과 양측 인공와우이식 아동의 숫자 판단하기의 반응시간이 정상청력 아동에 비해서 유의하게 길었으며, 일측 인공 와우이식 아동과 양측 인공와우이식 아동 간 숫자 판단하기의 반 응시간 차이는 유의하지 않았다. 듣기 조건에 대한 주효과도 유의 하게 나타나서, 숫자 판단하기의 반응시간이 조용한 조건에 비해 소음 조건에서 유의하게 길었다 $\left(F_{(1,48)}=22.479, p<.001\right.$, partial $\eta^{2}=.319$ ) (Figure 4).

\section{논의 및 결론}

본 연구에서는 이중과제를 이용하여 정상청력 아동, 양측 인공 와우이식 아동, 일측 인공와우이식 아동의 문장 판단하기와 숫자 판단하기의 수행력을 조용한 조건과 소음 조건에서 비교함으로써, 양측 인공와우이식이 청각장애 아동의 청각언어정보처리능력과 듣기 노력에 미치는 영향을 살펴보고자 하였다.

문장 판단하기의 정확도는 조용한 조건과 소음 조건에서 정상청 력 아동, 양측 인공와우이식 아동, 일측 인공와우이식 아동 순으로 유의하게 높았다. 본 연구에서의 문장 판단하기 과제에 사용된 문 장이 2어절로 구성된 비교적 쉬운 문장이었음에도, 양측과 일측 인 공와우이식 아동은 듣기 조건에 상관없이 정상청력 아동보다 유의 하게 낮았다. 이러한 결과는 인공와우로 전달되는 말소리의 질(quality)과 양(quantity)이 정상적인 청각 기능을 수행할 만큼 충분하지 않으며(Dunn et al., 2010), 양측 인공와우 착용시에도 청각장애 아 동의 취약한 청각 기능을 보완해주기 위한 $\mathrm{FM}$ 시스템과 같은 보조
기기의 사용이 필요하다는 것을 시사한다. 그리고 본 연구에서 양 측 인공와우이식 아동의 문장 판단하기 정확도가 조용한 조건과 소음 조건에서 일측 인공와우이식 아동보다 높았다. 이는 양측 인 공와우이식이 조용한 조건과 소음 조건에서의 말지각에 긍정적인 영향을 미친다고 보고한 선행연구(Eapen et al., 2009; Galvin et al., 2008; Lee \& Sim, 2015; Strøm-Roum, Laurent, \& Wie, 2012)의 결과 와 일치한다. 정상청력인 경우, 인간은 한쪽 귀로 들을 때보다 양쪽 귀로 들을 때 역치(threshold)보다는 $3 \mathrm{~dB}$, 일상 대화에서는 6-10 $\mathrm{dB}$ 크게 소리를 인식하는데, 이러한 현상을 음압가중효과(binaural summation effect)라고 하며, 일측에 청력 손실이 있을 경우에 음압가중효과가 감소되어 상대방의 말소리를 이해하는 능력이 떨 어지게 된다. 본 연구결과를 토대로 볼 때, 양측 인공와우이식 아동 에게도 음압가중효과가 적용되어, 일측 인공와우이식 아동에 비해 말소리 강도를 크게 인식하게 되어 중추 청각 수준에서의 말소리의 통합에 긍정적인 영향을 미친 것으로 볼수 있다(Ruggirello \& Mayer, 2010).

문장 판단하기의 반응시간은 조용한 조건과 소음 조건에서 정상 청력 아동, 양측 인공와우이식 아동, 일측 인공와우이식 아동 순서 로 유의하게 짧았다. 정상청력 아동은 조용한 조건과 소음 조건 간 에 문장을 판단하는 데 소요되는 시간의 차이가 미비한 반면에, 양 측과 일측 인공와우이식 아동은 조용한 조건에 비해 소음 조건에 서 문장을 판단하는 데 더 많은 시간이 소요되었다. 이는 감각장애 로 인해 특정 감각채널에 제한이 있을 때 정보처리의 효율성이 저 하된다는 노력가설(effortfulness hypothesis)을 지지하는 결과로 볼 수 있다(Pichora-Fuller \& Singh, 2006; Prodi, Visentin, \& Farnetani, 2010). 즉, 청각장애로 인해 말초청각수준에서 말소리를 정 확하게 지각하는 능력이 저하되면, 중추청각수준에서 말소리의 부 호화(decoding), 기억, 회상, 이해에 더 많은 인지 노력과 시간이 소 요되어 청각언어정보처리의 효율성이 저하되는 것이다. 본 연구에 서는 양측 인공와우 아동의 문장 판단하기의 반응시간이 일측 인 공와우이식 아동에 비해 유의하게 짧았다. 이러한 결과는 양측 인 공와우이식 아동이 일측 인공와우이식 아동보다 청각언어정보를 정확하고 빠르게 처리할 수 있다는 것을 시사한다. 양측 인공와우 이식 아동은 양이 청취로 말초청각수준에서의 말소리 지각이 향 상되어, 상향식(bottom-up approach)의 청각언어정보처리를 일측 인공와우이식 아동보다 효율적으로 할 수 있게 되는 것이다. 나아 가 양측 인공와우이식 아동은 정확하게 인지한 말소리를 본인의 언어지식을 활용하여 하향식(top-down approach)의 청각언어정 보처리에서도 유리한 조건을 지니게 되는 것이다.

숫자 판단하기 과제에서 정상청력 아동은 소음 유무에 따른 반 
응시간의 차이가 미비하였으나, 양측과 일측 인공와우이식 아동은 소음 조건에서의 반응시간이 조용한 조건에 비해 유의하게 길었다. 이는 정상청력 아동에 비해 인공와우이식 아동이 문장을 듣고 의 미적으로 판단하는 일차과제에 많은 집중과 인지 자원을 사용하게 되어 이차과제인 숫자 판단하기의 반응시간이 느려진 것으로 볼 수 있다. 본 연구에서 양측 인공와우이식 아동의 숫자 판단하기의 반 응시간이 일측 인공와우이식 아동에 비해서 짧았지만, 그 차이가 통계적으로 유의한 수준은 아니었다. 양측 인공와우이식 아동이 일측 인공와우이식 아동보다 문장을 더 정확하고 빠르게 판단하기 는 하지만, 여기에 소요되는 듣기 노력에는 큰 차이가 없다는 것을 의미한다.

본 연구를 통해, 양측 인공와우이식이 청각장애 아동의 듣기 노 력 감소에는 직접적인 영향을 미치지는 않더라도, 청각언어정보처 리의 정확성과 효율성 향상에 긍정적인 도움이 된다는 것을 확인 하였다. 조기에 양측 인공와우이식을 받아서 인공와우이식 간격 (inter-stage interval between implantation of the first and second ears)이 짧을수록 양이청의 극대화, 중추청각수준의 활성화, 언어 발달에서 더 큰 이득을 기대할 수 있으므로(Boons et al., 2012; Lee, 2014; Ruggirello \& Mayer, 2010; Sharma \& Campbell, 2011), 고도 이상의 청각장애 아동이 조기에 양측 인공와우이식을 시행 받아 서 청각언어정보처리의 활성화에 도움을 받을 수 있도록 할 필요 가 있겠다. 또한, 본 연구에서 양측과 일측 인공와우이식 아동 모두 조용한 조건에 비해 소음 조건에서 청각언어정보처리와 듣기 노력 이 저하된 것을 확인하였으므로, 소음을 줄이고 신호대잡음비를 높일 수 있도록 교실 환경을 개선하고 $\mathrm{FM}$ 시스템과 같은 청각적 지 원을 제공할 필요가 있겠다. 본 연구에서는 학령기에 속하는 인공 와우이식 아동만을 대상으로 하였으므로, 연구결과를 다양한 연 령대로 일반화시키기에는 제한이 있다. 그러므로 후속연구에서는 언어 발달이 급격하게 이루어지는 학령전 아동, 청소년 및 성인, 노 인 등의 청각언어정보처리 능력과 듣기 노력을 측정할 수 있는 다 양한 검사도구를 개발하여, 청력장애와 보장구에 따른 청각장애인 의 의사소통과 학습 상황에서의 청각언어정보처리와 듣기 노력에 관해 살펴보는 연구가 진행되어야 할 것이다.

\section{REFERENCES}

Baudonck, N., Lierde, K. V., D’haeseleer, E., \& Dhooge, I. (2011). A comparison of the perceptual evaluation of speech production between bilaterally implanted children, unilaterally implanted children, children using hearing aids, and normal-hearing children. International Journal of Audiology,
$50,912-919$

Boons, T., Brokx, J. P., Frijns, J. H., Peeraer, L., Philips, B., Vermeulen, A., ... \& Van Wieringen, A. (2012). Effect of pediatric bilateral cochlear implantation on language development. Archives of Pediatrics \& Adolescent Medicine, 166, 28-34.

Cho, H. Y. (2000). A Study on Korean vocabulary education. Seoul: Pagijong.

Choi, S., Lotto, A., Lewis, D., Hoover, B., \& Stelmachowicz, P. (2008). Attentional modulation of word recognition by children in a dual-task paradigm. Journal of Speech, Language, and Hearing Research, 51, 1042-1054.

Downs, D. W., \& Crum, M. A. (1978). Processing demands during auditory learning under degraded conditions. Journal of Speech \& Hearing Research, 21, 702-714.

Dunn, C. C., Noble, W., Tyler, R. S., Kordus, M., Gantz, B. J., \& Ji, H. (2010). Bilateral and unilateral cochlear implant users compared on speech perception in noise. Ear and Hearing, 31, 296-298.

Eapen, R. J., Buss, E., Adunka, M. C., Pillsbury, H. C., \& Buchman, C. A. (2009). Hearing-in-noise benefits after bilateral simultaneous cochlear implantation continue to improve 4 years after implantation. Otology \& Neurotology, 30, 153-159.

Flexer, C. A., \& Rollow, J. (2009). Classroom acoustics accessibility: a brain based perspective. Volta Voices, 16, 16-18.

Fraser, S., Gagné, J. P., Alepins, M., \& Dubois, P. (2010). Evaluating the effort expended to understand speech in noise using a dual-task paradigm: the effects of providing visual speech cues. Journal of Speech, Language, and Hearing Research, 53, 18-33.

Galvin, K. L., Mok, M., Dowell, R. C., \& Briggs, R. J. (2008). Speech detection and localization results and clinical outcomes for children receiving sequential bilateral cochlear implants before four years of age. International Journal of Audiology, 47, 636-646.

Goldberg, M. C., Maurer, D., Lewis, T. L., \& Brent, H. P. (2001). The influence of binocular visual deprivation on the development of visual-spatial attention. Developmental Neuropsychology, 19, 53-81.

Gosselin, P. A., \& Gagné, J. P. (2011). Older adults expend more listening effort than young adults recognizing speech in noise. Journal of Speech, Language, and Hearing Research, 54, 944-958.

Hicks, C. B., \& Tharpe, A. M. (2002). Listening effort and fatigue in schoolage children with and without hearing loss. Journal of Speech, Language, and Hearing Research, 45, 573-584.

Howard, C. S., Munro, K. J., \& Plack, C. J. (2010). Listening effort at signalto-noise ratios that are typical of the school classroom. International Jour- 
nal of Audiology, 49, 928-932.

Kahneman, D. (1973). Attention and effort. Englewood Cliffs, NJ: Prentice Hall Inc.

Kiessling, J., Pichora-Fuller, M. K., Gatehouse, S., Stephens, D., Arlinger, S., Chisolm, T., ... \& Rosenhall, U. (2003). Candidature for and delivery of audiological services: special needs of older people. International Journal of Audiology, 42(sup2), 92-101.

Killion, M. C. (1997). Hearing aids: past, present, future: moving toward normal conversations in noise. British Journal of Audiology, 31, 141-148.

Kim, K. (2003). Vocabularies for different levels of Korean education. Seoul: Pagijung.

Kim, Y. T., Hong, G. H., Kim, K. H., Jang, H. S., \& Lee, J. Y. (2009). Receptive \& expressive vocabulary test (REVT). Seoul: Seoul Community Rehabilitation Center.

Larsby, B., Hällgren, M., Lyxell, B., \& Arlinger, S. (2005). Cognitive performance and perceived effort in speech processing tasks: effects of different noise backgrounds in normal-hearing and hearing-impaired subjects. International Journal of Audiology, 44, 131-143.

Lee, M. Y., Shin, J. C., Kim, H. H., \& Kim, L. S. (2009). Open-set monosyllabic speech perception test for preschool children. Korean Journal of Otorhinolaryngology-Head and Neck Surgery, 52, 312-321.

Lee, Y. (2014). Effects of the inter-implant interval and listening condition on speech perception in children with sequential bilateral cochlear implants. Communication Sciences \& Disorders, 19, 564-573.

Lee, Y., \& Sim, H. (2015). Speech perception benefits of bilateral cochlear implantation for deaf children. Journal of Rehabilitation Research, 19, 175-193.

Miller, J. (1991). Reaction time analysis with outlier exclusion: bias varies with sample size. The Quarterly Journal of Experimental Psychology, 43, 907-912.

Noble, W., Tyler, R., Dunn, C., \& Bhullar, N. (2008). Unilateral and bilateral cochlear implants and the implant-plus-hearing-aid profile: comparing self-assessed and measured abilities. International Journal of Audiology, 47, 505-514.
Papso, C. F., \& Blood, I. M. (1989). Word recognition skills of children and adults in background noise. Ear and Hearing, 10, 235-236.

Pichora-Fuller, M. K., \& Singh, G. (2006). Effects of age on auditory and cognitive processing: implications for hearing aid fitting and audiologic rehabilitation. Trends in Amplification, 10, 29-59.

Picou, E. M., Ricketts, T. A., \& Hornsby, B. W. (2011). Visual cues and listening effort: individual variability. Journal of Speech, Language, and Hearing Research, 54, 1416-1430.

Plomp, R. (1994). Noise, amplification, and compression: considerations of three main issues in hearing aid design. Ear and Hearing, 15, 2-12.

Prodi, N., Visentin, C., \& Farnetani, A. (2010). Intelligibility, listening difficulty and listening efficiency in auralized classrooms. The Journal of the Acoustical Society of America, 128, 172-181.

Ruggirello, C., \& Mayer, C. (2010). Language development in a hearing and a deaf twin with simultaneous bilateral cochlear implants. Journal of Deaf Studies and Deaf Education, 15, 274-286.

Sarampalis, A., Kalluri, S., Edwards, B., \& Hafter, E. (2009). Objective measures of listening effort: effects of background noise and noise reduction. Journal of Speech, Language, and Hearing Research, 52, 1230-1240.

Sharma, A., \& Campbell, J. (2011). A sensitive period for cochlear implantation in deaf children. The Journal of Maternal-Fetal \& Neonatal Medicine, 24(suppl 1), 151-153.

SisaTimes. (2018). Children with hearing impairment are negatively affected by the classroom noise environment. http://sisatime.tistory.com/17322.

Strøm-Roum, H., Laurent, C., \& Wie, O. B. (2012). Comparison of bilateral and unilateral cochlear implants in children with sequential surgery. International journal of Pediatric Otorhinolaryngology, 76, 95-99.

Wackym, P. A., Runge-Samuelson, C. L., Firszt, J. B., Alkaf, F. M., \& Burg, L. S. (2007). More challenging speech-perception tasks demonstrate binaural benefit in bilateral cochlear implant users. Ear and Hearing, 28, 80S-85S.

World Health Organization. (2001). International Classification of Functioning, Disability, and Health (ICF). Geneva: Author. 
Appendix 1. 문장 판단하기 과제에 사용된 문장

\begin{tabular}{|c|c|c|c|c|}
\hline & 번호 & 문장 & 음절 수 & 정답 \\
\hline \multirow[t]{5}{*}{ 연습문항 } & 1 & 꽃은 예쁘다 & 5 & $\mathrm{O}$ \\
\hline & 2 & 바늘은 뾰족하다 & 7 & $\mathrm{O}$ \\
\hline & 3 & 이불은 포근하다 & 7 & $\mathrm{O}$ \\
\hline & 4 & 할머니는 젊다 & 6 & $x$ \\
\hline & 5 & 환자는 건강하다 & 7 & $x$ \\
\hline \multirow[t]{16}{*}{ 조용한 조건 } & 1 & 뱀은 길다 & 4 & $\mathrm{O}$ \\
\hline & 2 & 실은 굵다 & 4 & $x$ \\
\hline & 3 & 거인은 크다 & 5 & $\mathrm{O}$ \\
\hline & 4 & 여름은 춥다 & 5 & $x$ \\
\hline & 5 & 소금은 맵다 & 5 & $x$ \\
\hline & 6 & 밤은 환하다 & 5 & $x$ \\
\hline & 7 & 불은 뜨겁다 & 5 & $\mathrm{O}$ \\
\hline & 8 & 솜은 무겁다 & 5 & $x$ \\
\hline & 9 & 운동장은 넓다 & 6 & $\mathrm{O}$ \\
\hline & 10 & 우유는 까맣다 & 6 & $x$ \\
\hline & 11 & 초콜렛은 달다 & 6 & 0 \\
\hline & 12 & 칼은 위험하다 & 6 & $\mathrm{O}$ \\
\hline & 13 & 귀신은 무섭다 & 6 & $\mathrm{O}$ \\
\hline & 14 & 환자는 아프다 & 6 & 0 \\
\hline & 15 & 바나나는 빨갛다 & 7 & $x$ \\
\hline & 16 & 돼지는 날씬하다 & 7 & $x$ \\
\hline \multirow[t]{16}{*}{ 소음 조건 } & 1 & 달은 밝다 & 4 & $\mathrm{O}$ \\
\hline & 2 & 산은 높다 & 4 & $\mathrm{O}$ \\
\hline & 3 & 겨울은 덥다 & 5 & $x$ \\
\hline & 4 & 고추는 짜다 & 5 & $x$ \\
\hline & 5 & 기차는 짧다 & 5 & $x$ \\
\hline & 6 & 사탕은 쓰다 & 5 & $x$ \\
\hline & 7 & 김은 하얗다 & 5 & $x$ \\
\hline & 8 & 종이는 얕다 & 5 & $\mathrm{O}$ \\
\hline & 9 & 낮은 깜깜하다 & 6 & $x$ \\
\hline & 10 & 사과는 노랗다 & 6 & $x$ \\
\hline & 11 & 얼음은 차갑다 & 6 & $\mathrm{O}$ \\
\hline & 12 & 난장이는 작다 & 6 & $\mathrm{O}$ \\
\hline & 13 & 봄은 따뜻하다 & 6 & $\mathrm{O}$ \\
\hline & 14 & 아기는 귀엽다 & 6 & $\mathrm{O}$ \\
\hline & 15 & 달팽이는 빠르다 & 7 & $x$ \\
\hline & 16 & 거지는 불쌍하다 & 7 & $\mathrm{O}$ \\
\hline
\end{tabular}




\section{국문초록}

\section{이중과제 패러다임에서의 듣기 조건에 따른 양측 인공와우이식 아동의 문장 판단하기 및 듣기 노력} 이영미 · 심현섭

동명대학교 언어치료학과, 이화여자대학교 대학원 언어병리학과

배경 및 목적: 본 연구에서는 이중과제 패러다임을 이용하여 듣기 조건에 따른 양측 인공와우와이식 아동, 일측 인공와우이식 아동, 정상청력 아동의 청각언어처리능력과 듣기 노력 정도를 살펴보고자 하였다. 방법: 생활연령이 7-14세인 양측 인공와우이식 아동(17명), 일측 인공와우이식 아동(17명), 정상청력 아동(17명)을 대상으로 방음실에서 조용한 조건과 소음 조건에서 개별적으로 이중과제를 실 시하였다. 실험과제는 이중과제 패러다임에 근거하여 개발하였으며, 문장 판단하기를 일차과제로, 숫자 판단하기를 이차과제로 구성하 였다. 결과: 문장 판단하기의 정확도는 소음 조건보다 조용한 조건에서 유의하게 높았으며, 정상청력 아동, 양측 인공와우이식 아동, 일 측 인공와우이식 아동 순으로 유의하게 높았다. 문장 판단하기의 반응시간은 조용한 조건보다 소음 조건에서 유의하게 길었으며, 일측 인공와우이식 아동, 양측 인공와우이식 아동, 정상청력 아동 순으로 유의하게 길었다. 숫자 판단하기의 반응시간도 조용한 조건보다소 음 조건에서 유의하게 길었으며, 일측과 양측 인공와우이식 아동의 반응시간이 정상청력 아동에 비해 유의하게 길었다. 논의 및 결론: 본 연구에서는 양측 인공와우이식 아동의 청각언어처리능력과 듣기 노력이 정상청력 아동에 비해서는 낮지만, 동일한 듣기 노력을 사 용하더라도 일측 인공와우이식 아동에 비해 문장 수준의 청각언어정보를 더 정확하게 처리한다는 것을 확인하였다. 이는 언어 발달을 위한 청각언어처리 측면에서 양측 인공와우이식이 청각장애 아동에게 긍정적인 영향을 미칠 수 있음을 시사한다.

핵심어: 이중과제 패러다임, 양측 인공와우이식, 아동, 문장 판단하기, 듣기 노력

본 논문은 제1저자의 박사학위논문(2013)의 내용을 일부 발췌하여 수정·보완된 것임.

\section{참고문헌}

김광해(2003). 등급별 국어교육용 어휘. 서울: 박이정.

김영태, 홍경훈, 김경희, 장혜성, 이주연(2009). 수용·표현어휘력검사(REVT). 서울: 서울장애인종합복지관.

시사타임즈(2018). 난청아동 알아듣기 힘든 교실 소음 환경, 인지 발달에도 악영향. http://sisatime.tistory.com/17322

이미영, 신지철, 김향희, 김리석(2009). 학령전 아동의 단음절 말지각 검사 개발. 대한이비인후과학회지, 52, 312-321.

이영미(2014). 인공와우이식 간격과 듣기조건에 따른 순차적 양측 인공와우이식 아동의 말지각. 언어청각장애연구, 19, 564-573.

이영미, 심현섭(2015). 양측인공와우이식이 청각장애 아동의 말지각에 미치는 영향. 재활복지, 19, 175-193.

조현용(2000). 한국어 어휘교육 연구. 서울: 박이정. 